\title{
The Relationships between Vocational High School Teachers' Organizational Climate and Innovative Behavior
}

\author{
Umi Anugerah Izzati \\ Universitas Negeri Surabaya \\ Surabaya, Indonesia \\ umianugerah@unesa.ac.id
}

\begin{abstract}
This study aims to determine the relationship between organizational climate and innovative behavior of vocational school teachers. This research uses quantitative approach with total population of 70 vocational school teachers. Data collection uses an organizational climate scale and innovative behavior instrument. Data analysis techniques used is multiple regressions with the help of SPSS program. The results of this study indicate that the organizational climate has a positive relationship with innovative behavior in vocational school teachers. This means that the better the organizational climate in the vocational school teacher's workplace the stronger the teacher will be to demonstrate his innovative behavior in work.
\end{abstract}

Keywords:organizational climate, innovative behaviour

\section{INTRODUCTION}

Currently, vocational high schools are increasing in number. The large number of schools makes schools' stakeholders need to have a strategy in doing renewal in education. Schools need to have an update in order to stay up and grow, thus, innovation is always required. Innovation can be grown through teachers working in school education organizations. Teachers who have innovative behavior can support school performance. Yuan \& Woodman (2010) suggests that innovative behavior is the intention of employees to create, introduce, and implement new ideas within groups or organizations, which are intended to optimize organizational performance.

In the scope of the organization of vocational high school, many teachers lack the desire to innovate in work. This reality is obtained from a short interview conducted by researchers towards two principals and two vice principals at two vocational schools in Surabaya. The interview results indicate that teachers are comfortable in this school, so they do not want to develop new learning strategies and use only conventional learning strategies. The teachers here also rarely offer suggestions or new ideas for school progress. If there are new things that are socialized the school then not all teachers want to apply it.

Several research studies have increasingly shown the importance of organizations needing to understand how to identify the characteristics and behaviors of innovative people and their consequences, and how to promote and encourage innovative behavior within the organization (Patterson, 2009). This suggests that scientists and practitioners increasingly emphasize the importance of innovative behavior in the workplace, especially in educational organizations. In educational organizations, teachers play one of the most important roles in creating and maintaining effective schools (Balkar, 2015). Teachers who have innovative behavior are teachers who are able to work creatively and able to provide positive outcomes for the organization where they work. Innovative behavior can improve teachers' performance (Balkar, 2015). Innovative behavior also stimulates the generation of their more common and everyday ideas and practices (De Jong, 2007).

Studies showing the importance of innovative behavior were investigated, including research conducted by Etikariena \& Muluk (2014) finding that educational levels are a significant predictor of innovative behavior in the workplace. Meanwhile, research conducted by Basrawi (2012) revealed that emotional intelligence and intrinsic motivation have a positive and significant influence on the innovative behavior of elementary school teachers.

Based on the previous research above, currently innovative behavior is really needed to improve the field of education, organization, government, and in other fields of science. In the world of education, innovative behavior is manifested by a system of advocacy that uses applied methods. It is intended to answer the demands of the development of the era that always requires teachers to always behave innovatively in preparing their students in order to prepare themselves to face various problems that challenge their future (Prayudhayanti, 2014).

The innovative behaviors that should be developed in the education or school environment include innovations in: 1) curriculum development, 2) use of learning methods, 3) use of instructional media, 4) classroom management, 5) handling of students and 6) ways of assessment (Prayudhayanti , 2014).

It is important for schools to have innovative teaches. In addition, teachers who have innovative behavior are also seen as creative teachers who can create ideas and able to contribute to the progress of school. Teachers can answer the different needs and characteristics of students by using new strategies that help them to express their creativity in the learning process with innovative teaching (Balkar, 2015). Eaude (2011) argues that teacher innovation is necessary to enhance students' learning and that the teaching profession requires pedagogy including innovation. A good school climate and work environment needed to support teachers should also be provided to ensure the effectiveness of the teachers' performance as expected. Amabile (1988 in Sari \& Ulfa, 2013) 
states that work environments that affect the behavior of innovation must meet several provisions: a) provide the impetus to take risks, b) be fair and supportive of ideas, c) respect and acknowledge innovation, d) collaborate ideas that continue to flow, and e) participate in making decisions.

Several previous research studies have proved that many factors can influence teachers' innovative behavior. One of the factors that influence innovative behavior is the organizational climate. Research conducted by Sari and Ulfa (2013), and Noor and Dzulkifli (2013) revealed that organizational climate has a positive effect on innovative work behavior, meaning that the better organizational climate perceived by employees the higher the innovative behavior in the work of the employee. According to Stringer (2002) there are six organizational climate components:

1. Structure relates to how employees are given explanation and understanding of the tasks that must be done in the workplace.

2. Standards are a sense of pride that will arise among the employee after completing work.

3. Responsibility is associated with the work of the employee whether it is in accordance with the assigned or not.

4. Recognition is a reward that will be given to the employee if they have achieved more work than the standard work.

5. Support is related to the supportive attitude that the coworker provides when the employee is working on the task.

6. Commitment relates to the totality of employees who desire to advance, achieve goals, and provide the best performance for where the employee works.

The Balkar (2015) did a study towards elementary school teachers in Turkey showing that organizational climate is important in creating conditions to ensure high-performance teachers and encouraging them to demonstrate innovative behavior both in class and in school. While the study conducted by De Jong (2007) found that there is a relevant leadership behavior. Leaders can influence employees' innovative behavior through their actions aimed at stimulating the generation of their more common and everyday ideas and practices.

Sağnak (2012) also points out that there is a sig-nificant relationship between innovative climates and teachers' innovative behavior. So far, organizational climate research and innovative behavior have more to do with industry and elementary schools. To the knowledge of research, research about the organizational climate and innovative behaviors conducted on vocational high school teachers in educational institutions has not been conducted. Therefore, this research is related to organizational climate and innovative behavior in teachers of vocational high schools who work in one of the educational foundations in Surabaya. Based on the description of other research above, what distinguishes this research with previous research is research-based education, as well as subjects used, i.e. teachers of vocational high schools. This study attempts to answer the following research questions: Is there a relationship between organizational climate and innovative behavior in vocational school teachers?$$
2
$$

\section{METHOD}

This study was conducted using quantitative research methods. The research design is a field study. Sample criterion taken in this research is teacher in vocational school who are at least 22 years old and have minimum education of S1. In this study, the total population of two vocational secondary schools in Surabaya is located in one Foundation Education so that the number of subjects of this research is 70 people. This study uses a scale instrument. There are two scales used: organiza-tional climate scale and innovative behavior scale. The instrument used in this study resulted in a significant value smaller than 0.05 with the value of cronbac alpha on the organizational climate scale of 0864 and the value of cronbac alpha scale inno-vative behavior of 0.895 , so it can be stated that the scale of research is reliable. As for the validity of organizational climate scale ranges from $0.479 \mathrm{~s} / \mathrm{d} 0.779$ and innovative behavior scale ranges from $0.428 \mathrm{~s} / \mathrm{d} 0.631$. This indicates that the scale of organizational climate as well as the scale of inotive behavior is valid and reliable. The collected data was analyzed by using multiple regression with SPSS 20.

\section{RESULT AND DISCUSSION}

Pallant (2007) states that if the value of significance is less than 0.05 then Ho is rejected and $\mathrm{Ha}$ is accepted, or in other words there is a relationship between variables $\mathrm{X}$ and $\mathrm{Y}$. Here is a table of regression analysis results in this study.

Table 1. Regression Analysis Results

\begin{tabular}{cccccc}
\hline \multirow{2}{*}{ Model } & \multicolumn{2}{c}{$\begin{array}{c}\text { Unstandardized } \\
\text { Coefficients }\end{array}$} & $\begin{array}{c}\text { Standard } \\
\text { ized } \\
\text { Coeffici } \\
\text { ents }\end{array}$ & $\mathrm{t}$ & Sig. \\
\cline { 2 - 4 } & $\mathrm{B}$ & $\begin{array}{c}\text { Std. } \\
\text { Error }\end{array}$ & Beta & & \\
\hline 1 (Constant) & .473 & .150 & & 3.144 & .003 \\
Structure & .123 & .059 & .195 & 2.096 & .040 \\
Standard & .121 & .052 & .169 & 2.315 & .024 \\
Responsibility & .115 & .056 & .181 & 2.054 & .044 \\
Recognition & .151 & .073 & .195 & 2.075 & .042 \\
Support & .097 & .044 & .154 & 2.194 & .032 \\
Commitment & .191 & .061 & .246 & 3.136 & .003 \\
\hline
\end{tabular}

\section{a. Dependent Variable: PI}

The results of this study indicate that there is a positive correlation between organizational climate and innovative behavior of vocational high school teachers that can be viewed from the results of regression analysis on each dimension of innovative behavior.

Tests on the effect of structural variables on innovative behavioral variables resulted in $\mathrm{t}$ count of 2.096 with a significance value of 0.040 , which means that vocational high school teachers who have a clear definition of roles and responsibilities in work can bring innovative behavior.

Tests of the effect of standard variables on variable organizational behavior generated t count of 2.315 with a 
significance value of 0.024 , which means vocational high school teachers are proud and happy with his work can bring up innovative behavior.

Testing the influence of the variable of responsibility to the variable of organizational behavior generated $t$ count equal to 2,054 with significance value 0,044 , meaning that vocational high school teachers who have independence in completing the work can bring innovative behavior.

The test of the influence of reward variable on organizational behavior variable is $\mathrm{t}$ arithmetic equal to 2,075 with a significance value of 0.042 , meaning that vocational high school teachers who get the appropriate rewards or salary after completing their work can bring up innovative behavior.

Testing the influence of variable support to organizational behavior variables generated $\mathrm{t}$ count equal to 2,194 with a significance value of 0.032 , which means that vocational high school teachers who have good relationships with colleagues can bring innovative behavior.

Testing the influence of commitment variables on organizational behavior variables generated t count of 3.136 with a significance value of 0.003 , which means that vocational high school teachers who feel involved in achieving organizational goals can bring innovative behavior.

Based on the results of data analysis, the coefficient of determination is 0.820 . This value indicates that variations in innovative behavior data can be explained by the organizational climate consisting of structural, standard, responsibility, reward, support and commitment variables. In other words, the overall climate of the organization has an $82 \%$ effect on innovative behavior. Teachers with good perceptions of good school organization climate include clarity of task structure, standards, responsibility, recognition, support and commitment to make teachers have innovative behavior. The existence of innovative behavior will be able to support the achievement of school organizational performance. While $18 \%$ is influenced by other variables that influence innovative behavior.

The results of this study are in line with research conducted by Sağnak (2012) which suggests that there is a significant relationship between innovative climate and innovative behavior of teachers. This indicates that the better and conducive the organizational climate felt by teachers, the higher the innovative behavior in working from the teacher. In contrast to that, if the less organizational climate, the lower the innovative behavior in working from the teacher.

\section{CONCLUSION}

This study concludes that the organizational climate has a relationship with innovative behavior in Vocational High School teachers. The better and conducive the organizational climate is perceived by the teacher, the higher the teacher's innovative behavior in work. And vice versa, the less conducive the organizational climate felt by the teacher, the lower the innovative behavior in working from the teacher. This study has limitations, namely the number of limited subjects that is one of the foundations of education in
Surabaya. While the number of secondary schools in Surabaya consisting of public and private vocational schools are a lot. In addition, this study has not looked at other variables that can influence innovative behavior.

\section{REFERENCES}

Balkar, B. 2015. The Relationships between Organizational Climate, Innovative Behavior and Job Performance of Teachers. International Online Journal of Educational Sciences, 7 (2), 81-92.

Basrawi, I., F. 2012. Pengaruh kecerdasan emosional dan motivasi intrinsik terhadap perilaku inovatif guru sekolah dasar. Disertasi Universitas Airlangga Surabaya.

De Jong, J. 2007. Individual innovation : the connection between leadership and employee's innovative work behavior. Dissertation Faculty of Economics and Business. University of Amsterdam.

Eaude, T. 2011. Compliance or innovation? Enhanced professionalism as the route to improving learning and teaching. Education Review, 23(2), 49-57.

Etikariena \& Muluk. 2014. Hubungan antara memori organisasi dan perilaku inovatif karyawan. Universitas Indonesia.

Noor, H.M., and Dzulkifli $\quad$ B. 2013. Assessing Leadership Practices, Organizational Climate and Its Effect towards Innovative Work Behaviour in R\&D. International Journal of Social Science and Humani-ty. 3(2), pp: 129133.

Pallant, J. 2007.SPSS:Survival Manual (3rd. ed). Sydney: Allen \& Unwin.

Patterson, F., Kerrin, M., \& Gatto-Roissard, G. 2009. Characteristics and Behaviours of Innovative People in Organizations. Literature Review Prepared for the NESTA Policy \& Research Unit, 1-63.

Prayudhayanti, B., N. 2014. Peningkatan Perilaku Inovatif melalui Budaya Organisasi. Jurnal Ekonomi Bisnis, 15(2), 19-32.

Sağnak, M. 2012. The empowering leadership and teach-ers' innovative behavior: The mediating role of in-novation climate. African Journal of Business Manage-ment, 6(4), 1635-1641. doi:10.5897/AJBM11.2162.

Sari, A.N., dan Cherly, K.U. 2013. Perilaku Inovasi Karyawan Ditinjau dari Empat Kuadran Iklim Or-ganisasi.

Yuan, F., \& Woodman, R.W. 2010. Innovative Behavior in the Workplace : The Role Performance and Image Outcomes Expectation, Academy of Management Journal, 53 (2), 323-343. 